\title{
Is Prolonged Stress Causes Poly Cystic Ovarian Syndrome? A Survey from Delhi, National Capital Region
}

\author{
Anjana Goyal ${ }^{1}$, Reena Doomra ${ }^{2}$, Neha Atkaan ${ }^{3}$, Shiny Singh ${ }^{4}$, Shreya Bhatia ${ }^{5}$ \\ 1, 3, 4,5 Department of Biochemistry, Manav Rachna Dental College, Faridabad, Haryana, India. \\ ${ }^{2}$ Department of Pharmacology, Manav Rachna Dental College, Faridabad, Haryana, India.
}

\section{ABSTRACT}

\section{BACKGROUND}

Poly cystic ovarian syndrome (PCOS) is a common endocrine ovarian disorder found to be affecting $6-26 \%$ of female respondents globally. ${ }^{1}$ Symptoms include hirsutism, anovulation and psychological factors like severe mood swings, depression etc. Stress, which is majorly caused by unhealthy lifestyle, especially in prolonged cases alters the metabolism of body and causes severe diseases like PCOS and decreases the efficiency of females. This study aims to evaluate as to whether stress is one of the major hidden reasons for PCOS in the females of Delhi-NCR (National Capital Region).

\section{METHODS}

120 female students had given their consent to fill an online questionnaire made on Google forms and were distributed via WhatsApp. The form consisted of 31 questions distributed over stress and symptoms of PCOS.

\section{RESULTS}

Efficiency of $54.5 \%$ of the respondents had decreased in the absence of sound sleep as they mostly experienced 'situational stress'. Recurrence of sleeplessness had led to anger in $71 \%$ of above respondents. It was also observed that $55 \%$ of the respondents had a sign of early reproductive / late adolescence and they experienced irregular menstrual cycle along with facial hair, stretch marks, acne and severe hair fall.

\section{CONCLUSIONS}

$57 \%$ of the respondents had both stress and symptoms of PCOS. Modifications in their lifestyles / dietary habits could control and improve the situation. Healthy lifestyle certainly helps in the treatment but is not a complete cure for PCOS.

\section{KEY WORDS}

Stress, PCOS, Lifestyle, Psychological Analysis
Corresponding Author:

Dr. Anjana Goyal,

5 GF, Lilac-1, Sector 49,

Sohna Road, Gurugram,

Haryana, India.

E-mail: goyalanjana17@gmail.com

DOI: $10.14260 / j e m d s / 2021 / 110$

How to Cite This Article:

Goyal A, Doomra R, Atkaan N, et al. Is prolonged stress causes poly cystic ovarian syndrome? a survery from Delhi, National capital region. J Evolution Med Dent Sci 2021;10(08):505-510, DOI: $10.14260 /$ jemds/2021/110

Submission 15-10-2020,

Peer Review 24-12-2020,

Acceptance 30-12-2020,

Published 22-02-2021.

Copyright (c) 2021 Anjana Goyal et al. This is an open access article distributed under Creative Commons Attribution License [Attribution 4.0 International (CC BY 4.0)] 


\section{BACKGROUND}

PCOS was first described in 1935 as a 'triad of amenorrhea, obesity and hirsutism' by Irvin Stein and Michael Leventhal, ${ }^{2}$ when they detected the relation between obesity and reproductive disorders. ${ }^{3}$ It is also called "Stein-Leventhal syndrome" or "Hyperandrogenic Anovulation" (HA) ${ }^{1}$ as increased levels of androgen are also seen in the patients.

$\mathrm{HA}$ is most common endocrine ovarian disorder found to be affecting 6-26\% of females manifesting an incidence rate of $9.13 \%, 4,5,6,7,8,9$ affecting women of age group of 15 to 44 or the 'reproductive age group'.10

Symptoms consist of a combination ${ }^{11}$ of metabolic and psychological factors with metabolic derangements ${ }^{8}$ consisting of insulin resistance, ${ }^{9}$ compensatory hyperinsulinemia, 123 times increased risk of type II diabetes mellitus, ${ }^{11}$ which is generally found in $60-80 \%$ of female with PCOS, ${ }^{21}$ some studies even suggest that there may be an 'eightfold' increase in risk of getting T2DM, ${ }^{13}$ gestational diabetes, ${ }^{14}$ chronic low grade inflammation ${ }^{15} \&$ obesity. The psychological factors being various mood swing disorders, ${ }^{16}$ chronic stress, social fears, reduced quality of life, ${ }^{17}$ depression ${ }^{18}$ and sleep apnoea, ${ }^{19}$ which is $5-10$ times higher in women with obesity issues. ${ }^{20}$ The main observable characteristics are as follows. ${ }^{21}$

\section{Ovulatory Dysfunction}

(Extremely Irregular Cycle) - Ovulation may or may not occur [anovulation].22 oligomenorrhea, infertility and dysfunctional uterine bleeding disorders, 22 and increased risk of Endometrial Cancer. ${ }^{23}$

\section{Polycystic Ovaries}

Seen in pelvic ultrasounds of numerous patients with PCOS 24 and hyperandrogenism (abnormal increase of androgen hormone in blood). ${ }^{22}$

\section{Other Symptoms}

- Acne.

- Seborrhoea.

- Hirsutism.

- Alopecia.

- $\quad$ Frank virilisation. ${ }^{24}$

Often called most common cause of an ovulatory infertility in women, 22,25 not a perfect causal factor known, but there are evidence proving that both environmental as well as genetic factors, play a role in its aetiology, ${ }^{26}$ however obesity and stress does exacerbate many aspects of phenotype, especially cardiovascular risk factors such as glucose intolerance and dyslipidemia. Whereas, it also has been observed from various patients that symptoms of depression and chronic stress, account for risk factors for cardiovascular morbidity and mortality as well as for T2DM, particularly in the presence of other risk factors and/or pre-existing morbidity. ${ }^{27}$

Till date, the treatment of PCOS is done on the basis of symptoms only. ${ }^{28}$ Nowadays, with increasing number of cases, symptomatic treatment alone has not emerged as efficient method and doctors have started taking the line of treatment, which consists of advising patients with a change in 'lifestyle'. These changes may include, making dietary regulations and devoting some time to exercise as well so as to reduce weight. Various studies have also revealed that reducing even 8-10\% of the body weight can aid in regulating a patient's menstrual cycle and enhance symptoms of PCOS.29

Studies have shown that 30 minutes of moderate intensity exercise at least 3 days/week can help women with PCOS lose weight. Losing weight by exercising also improves ovulation and insulin levels. ${ }^{30}$ Exercises prove to be even more beneficial when combined with a healthy diet. Diet, with some routine based exercises help a female to lose more weight and it lowers risks for diabetes and heart diseases as well.

Studies comparing diets for PCOS have found that low carb diets $^{31}$ are effective for both weight loss and lowering insulin levels. A low glycemic index diet that gets most carbs from fruits, vegetables and whole grains helps regulate the menstrual cycle better than a regular weight loss diet.

\section{Medication}

Doctors worldwide seem to favour 2 main medicines, ${ }^{32}$ as for the treatment of PCOS.

\section{Birth Control Pills}

Birth Control Pills and other red medicines can help regulate menstrual cycle and treat PCOS symptoms like hair growth and acne, caused as an effect of hyperandrogenism.

\section{Metformin (Glucophage, Fortamet)}

It is a drug used to treat type 2 diabetes mellitus. It also aids in treating PCOS by lowering insulin levels.

One such study on PCOS found that having metformin, while making certain changes in diet and exercise, seems to improve weight loss, lowers blood sugar and restores a normal menstrual cycle, better than changes to diet and exercise alone. ${ }^{33}$

Under normal conditions, the pituitary gland secretes FSH and LH every month, required for the normal process of menstruating. These hormones on reaching ovaries, start maturing eggs, expanding follicle size and secreting oestrogen. During PCOS, the secretion of LH seems to increase due to decrease in GnRH and LH inhibitory neurotransmitters namely Serotonin, Dopamine, GABA and Acetylcholine, and certain increase in major stimulatory hormone called Glutamate.

Research also shows an increase in GnRH and LH activity in PCOS condition, which is likely the result of constant effect of altered LH stimulatory and inhibitory neurotransmitters in hypothalamic-pituitary centre. Thus, it is assumed that this can be the reason, responsible for depression, stress and anxiety-like mood disorders which are commonly encountered with women having PCOS.

During any kind of stress, amygdala recognises the threat, sends message to hypothalamus which releases CorticotropinReleasing Hormone ( $\mathrm{CRH}$ ) which then signals pituitary gland to release Adreno Cortico Tropic Hormone (ACTH), which further stimulates adrenal glands to produce cortisol. Thus, 
forming the Hypothalamus-Pituitary-Adrenocortical (HPA) axis. ${ }^{34}$

If the above phenomena occur for a very long duration, the cortisol starts affecting other systems like suppressing the immune system, increase blood sugar levels causing hyper glycemia, (in response to which, insulin is secreted from pancreas) produces acne and contributes to obesity etc.

Stress $\rightarrow$ Cortisol $\rightarrow$ Blood Sugar Increased $\rightarrow$ Insulin

In PCOS,

Abnormal amount of LH+ Insulin $\rightarrow$ Hyperandrogenism ${ }^{35}$

As a combination of above two responses, androgen is produced which, due to abnormal mechanisms of the body, cannot be changed into oestrogen. Therefore, it can be stated that-'The symptoms that occur under PCOS are half of hyperandrogenism ${ }^{36}$ and the other half of hypercortisolism. ${ }^{37}$

\begin{tabular}{|cc|}
\hline High Androgenic & High Cortisol \\
\hline Irregular menstrual cycle & Acne \\
Too much hair on face (hirsutism) & Weight gain \\
\hline Thinning hair & \\
\hline Darkening of skin (A. nigricans) & \\
\hline Skin tags & \\
\hline Table 1. Symptoms in High Androgenic and High Cortisol States \\
\hline
\end{tabular}

PCOS is a life-long disease which currently, seems that can never be cured but the only way to manage this unpleasant and distressing disease, is to continue the medications for the rest of patients' life. But, if the medication is not taken properly or if it is misdiagnosed or dealt with a negligent attitude, it may cause some serious diseases, namely, endometrial cancer, diabetes type $\mathrm{II},{ }^{18}$ heart disease, ${ }^{18}$ sleep disorders, ${ }^{19}$ moodanxiety disorders, ${ }^{16}$ depression ${ }^{18}$ and, the most common, infertility. ${ }^{22}$

\section{METHODS}

The study, in the form of survey, was conducted after taking approval from institutional head. A cross-sectional survey of female respondents in the age group of 15 to 25 years was carried out in 'Manav Rachna Educational Institute (MREI), Faridabad', a university of Delhi / NCR to corroborate the reasons for PCOS caused due to prolonged stress. A questionnaire was prepared and tested on peer group female students to carry out a pilot study and validate the questions.

The study was conducted during the Covid-19 pandemic period, during which it was decided to circulate the questionnaire through online WhatsApp / social media. A total number of 120 females were approached with their consent. All of them were provided with brief introduction about the survey. The confidentiality of the person's identity was maintained. Incomplete responses were excluded from data capturing and data analysis thus the effective respondents for the study were 100 female students. A self-constructed, close ended questionnaire of 31 questions was prepared on Google forms and circulated via WhatsApp and Gmail to all the female respondents which consisted of 3 parts - a) General information on profile and lifestyle habits b) Stress related issues and 3) PCOS symptoms.

\section{Statistical Analysis}

Statistical analysis was done using frequency distribution of responses by using Statistical Package for Social Science Software (SPSS). Stress reported by the respondents was analysed by the online stress assessment tool 'Stress Coping Resources Inventory'.

\section{RESULTS}

A total of 120 respondents had participated in survey, which consisted of female respondents in the age group of 15 to 25 years. Group was further divided as 'adolescents' in the age of 15 - 20 years and 'Reproductive' in the age group of $21-25$ years. Out of 120 participants, 100 respondents responded by filling the form completely, hence, 100 respondents were included in inclusion criteria. Out of the 100 participants, $34 \%$ were 15 to 20 years age group and $66 \%$ were 21 - 25 years age group. $\mathrm{P}$ value $<0.05$ was taken significant.

Among the respondents, $52.95 \%$ in adolescents and 39.41 $\%$ in reproductive age group were of science stream. Among these students, $29.42 \%$ in adolescents and $36.37 \%$ in reproductive age group had opted for medical. In the remaining respondents, $11.77 \%$ in adolescents and $34.85 \%$ in reproductive age group were from commerce, $8.83 \%$ in adolescents and $12.13 \%$ in reproductive age group were from humanities and balance $26.48 \%$ in the adolescents and 13.64 $\%$ in reproductive age group were from other courses.

$8.83 \%$ respondents in adolescents and $12.13 \%$ in reproductive age group had more than $8 \mathrm{hrs}$. of study in the college while the rest- $23.53 \%$ in adolescents and $53.04 \%$ in reproductive age group, had less than $8 \mathrm{hrs}$. of study in college. $52.95 \%$ in adolescents and $27.78 \%$ in the reproductive age group had a sleep of less than 8 hours and $47.07 \%$ in adolescents and $72.72 \%$ in reproductive age group had sufficient sleep of 8 hours or more.

Survey had shown that the stress was also one of the major factors affecting young generation among students and had affected significantly lives of $47 \%$ of the adolescents and 24.24 $\%$ reproductive age group population.

Survey also showed the type of stress faced by these students. $76.47 \%$ in the adolescents and $48.49 \%$ in reproductive age group mentioned that the type of stress as causal situational stress, which resulted due to emergencies or certain situations creating burden. $11.76 \%$ of adolescents and $22.73 \%$ reproductive age group population mentioned that the cause for stress was time (time stress) and were affected due to deadlines or from schedule. $5.88 \%$ of adolescents and $21.22 \%$ of reproductive age group had confessed that they were having 'other reasons' for stress.

$44.11 \%$ of adolescents and $72.73 \%$ of reproductive age group population notice increase in anger commonly while $32.35 \%$ of adolescents and $7.58 \%$ of reproductive age group crowd stated that anger increased only on some occasions or otherwise remained clam, while $23.52 \%$ of adolescents and $19.7 \%$ of reproductive age group people said that they haven't experienced any such increase.

$8.83 \%$ in adolescents and $25.15 \%$ in reproductive age group population responded that physical activity in the form of exercise on daily routine basis was dependent upon time availability as they were busy in their study, work schedules 
and day to day activity. $52.95 \%$ in adolescents and $63.63 \%$ in reproductive age group of the students responded in negation. Though $38.24 \%$ in adolescents and $10.6 \%$ in reproductive age group population agreed to have exercise as part of their routine.

\begin{tabular}{|c|c|c|c|c|c|c|}
\hline $\begin{array}{l}\text { Sl. } \\
\text { No. }\end{array}$ & Question & Responses & $\begin{array}{l}\text { Age Group } \\
15-20 * \text { yrs }\end{array}$ & $\begin{array}{l}\text { Age Group } \\
21-25^{\wedge} \text { yrs }\end{array}$ & $\chi^{2}$ & $\begin{array}{c}P \\
\text { Value }\end{array}$ \\
\hline 1 & Age group & & $34 \%$ & $66 \%$ & & \\
\hline 2 & Stream & $\begin{array}{c}\text { Science (med) } \\
\text { Science (non med) } \\
\text { Commerce } \\
\text { Humanities } \\
\text { others }\end{array}$ & $\begin{array}{c}10(29.42 \%) \\
8(23.53 \%) \\
4(11.77 \%) \\
3(8.83 \%) \\
9(26.48 \%)\end{array}$ & $\begin{array}{c}24(36.37 \%) \\
2(3.04 \%) \\
23(34.85 \%) \\
8(12.13 \%) \\
9(13.64 \%)\end{array}$ & 16.4 & 0.002 \\
\hline 3 & $\begin{array}{c}\text { Average } \\
\text { Hours of } \\
\text { study }\end{array}$ & $\begin{array}{l}\text { Less than } 8 \\
\text { More than } 8\end{array}$ & $\begin{array}{l}8(23.53 \%) \\
36(8.83 \%)\end{array}$ & $\begin{array}{l}35(53.04 \%) \\
31(46.97 \%)\end{array}$ & 7.96 & 0.004 \\
\hline 4 & $\begin{array}{l}\text { Average } \\
\text { Hours of } \\
\text { sleep }\end{array}$ & $\begin{array}{l}\text { Less than } 8 \mathrm{hrs} \\
8 \text { - } 10 \mathrm{hrs} \\
\text { More than } 8 \mathrm{hrs}\end{array}$ & $\begin{array}{c}18(52.95 \%) \\
14(41.18 \%) \\
02(5.89 \%)\end{array}$ & $\begin{array}{l}18(27.28 \%) \\
17(25.76 \%) \\
31(46.96 \%)\end{array}$ & 17.3 & 0.0001 \\
\hline $5^{1}$ & $\begin{array}{l}\text { Involvement } \\
\text { in Physical } \\
\text { activity }\end{array}$ & $\begin{array}{c}\text { Yes } \\
\text { No } \\
\text { Occassional }\end{array}$ & $\begin{array}{c}13(38.24 \%) \\
18(52.95 \%) \\
03(8.83 \%)\end{array}$ & $\begin{array}{c}07(10.6 \%) \\
42(63.63 \%) \\
17(25.15 \%)\end{array}$ & 12.21 & 0.002 \\
\hline 6 & $\begin{array}{c}\text { Consumptio } \\
\mathrm{n} \text { of } \\
\text { Balanced } \\
\text { diet }\end{array}$ & $\begin{array}{c}\text { Yes } \\
\text { No } \\
\text { Occassional } \\
\text { Not possible } \\
\text { (circumstaintial) }\end{array}$ & $\begin{array}{c}2(5.89 \%) \\
15(44.12 \%) \\
3(8.83 \%) \\
13(38.24 \%)\end{array}$ & $\begin{array}{c}13(19.69 \%) \\
41(62.12 \%) \\
4(6.06 \%) \\
8(12.12 \%)\end{array}$ & 11.7 & 0.008 \\
\hline 7 & $\begin{array}{l}\text { Consumptio } \\
\text { n of Junk } \\
\text { Food }\end{array}$ & $\begin{array}{c}\text { Never } \\
\text { Occassionally } \\
\text { Regularly }\end{array}$ & $\begin{array}{c}9(26.48 \%) \\
7(20.59 \%) \\
18(52.95 \%)\end{array}$ & $\begin{array}{c}4(6.06 \%) \\
41(62.12 \%) \\
21(31.82 \%)\end{array}$ & 17.8 & 0.0001 \\
\hline \multicolumn{7}{|c|}{ Table 2. General Information on Profile and Lifestyle Habits } \\
\hline *adol & lescents' popu & ulation ${ }^{\wedge}$ reproducti & ive population & & & \\
\hline
\end{tabular}

\begin{tabular}{|c|c|c|c|c|c|c|}
\hline $\begin{array}{l}\text { Sl. } \\
\text { No. }\end{array}$ & Question & Responses & $\begin{array}{l}\text { Age Group } \\
15 \text { - } 20 \text { yrs }\end{array}$ & $\begin{array}{l}\text { Age Group } \\
21-25 \text { yrs }\end{array}$ & $\chi^{2}$ & $\begin{array}{c}P \\
\text { Value }\end{array}$ \\
\hline 1 & $\begin{array}{l}\text { Is stress } \\
\text { effecting life? }\end{array}$ & $\begin{array}{c}\text { Yes } \\
\text { No } \\
\text { Occassionally } \\
\text { Don't know }\end{array}$ & $\begin{array}{l}16(47 \%) \\
4(11.7 \%) \\
7(20.5 \%) \\
6(17.6 \%)\end{array}$ & $\begin{array}{c}16(24.24 \%) \\
28(42.42 \%) \\
8(12.13 \%) \\
14(21.22 \%)\end{array}$ & 11.55 & 0.009 \\
\hline 2 & $\begin{array}{l}\text { Reasons for } \\
\text { stress }\end{array}$ & $\begin{array}{l}\text { Time mgmt } \\
\text { Situational } \\
\text { Others }\end{array}$ & $\begin{array}{c}4(11.76 \%) \\
26(76.47 \%) \\
4(11.76 \%)\end{array}$ & $\begin{array}{c}15(22.73 \%) \\
32(48.49 \%) \\
19(28.8 \%)\end{array}$ & 7.83 & 0.04 \\
\hline 3 & $\begin{array}{l}\text { Observation } \\
\text { of increase in } \\
\text { Anger }\end{array}$ & $\begin{array}{c}\text { Yes } \\
\text { No } \\
\text { Little bit }\end{array}$ & $\begin{array}{c}15(44.11 \%) \\
8(23.52 \%) \\
11(32.35 \%)\end{array}$ & $\begin{array}{c}48(72.73 \%) \\
13(19.7 \%) \\
5(7.58 \%)\end{array}$ & 11.6 & 0.002 \\
\hline \multicolumn{7}{|c|}{ Table 3. Stress Related Issues } \\
\hline
\end{tabular}

$44.12 \%$ in adolescents and $62.12 \%$ in reproductive age group, believed in taking balanced diet and followed as far as possible. $26.48 \%$ in adolescents and $6.06 \%$ in reproductive age group, consumed junk food occasionally whilst, $52.95 \%$ in adolescents and $31.82 \%$ in reproductive age group population responded that by stating that it was not possible to exclude from their routine.

None of the participants went through a blood test recently to check the level of hormones (LH- Luteinizing hormone and FSH- Follicular-stimulating hormone). $70.58 \%$ of people in adolescents and $48.49 \%$ of people in reproductive age group population, attained menarche by 15 years or below and 52.94 $\%$ in adolescents and $21.22 \%$ in reproductive age group population in respondents faced irregular periods during their menstrual cycles right from the beginning. The survey results also showed that $29.41 \%$ in adolescents and $59.1 \%$ in reproductive age group population, had their cycle lasting for more than a week. $32.35 \%$ in adolescents and $56.07 \%$ in reproductive age group respondents experienced light flow, $8.82 \%$ in adolescents and $56.07 \%$ in reproductive age group population followed very light or scanty flow and a few experienced a very heavy flow i.e., $20.58 \%$ in adolescents and $7.58 \%$ in reproductive age group population. Since lower abdominal pains are common during menstruation, $47 \%$ in adolescents and $71.22 \%$ in reproductive age group population encountered pain in pelvic region during their periods and $32.35 \%$ in adolescents and $51.52 \%$ in reproductive age group population had the pain throughout their bleeding phase.

\begin{tabular}{|c|c|c|c|c|c|c|}
\hline $\begin{array}{l}\text { Sl. } \\
\text { No. }\end{array}$ & Question & Responses & $\begin{array}{l}\text { Age Group } \\
15-20 \text { yrs }\end{array}$ & $\begin{array}{l}\text { Age Group } \\
21 \text { - } 25 \text { yrs }\end{array}$ & $\chi^{2}$ & $\begin{array}{c}\mathbf{P} \\
\text { Value }\end{array}$ \\
\hline 1 & Menarche & $\begin{array}{c}<15 \mathrm{yrs} \\
16-18 \\
>19 \mathrm{yrs}\end{array}$ & $\begin{array}{c}24(70.58 \%) \\
6(17.64 \%) \\
4(11.76 \%)\end{array}$ & $\begin{array}{c}32(48.49 \%) \\
8(12.13 \%) \\
26(39.4 \%)\end{array}$ & 8.15 & 0.01 \\
\hline 2 & $\begin{array}{l}\text { Menstrual } \\
\text { Cycle }\end{array}$ & $\begin{array}{c}\text { Regular } \\
\text { Irregular } \\
\text { (since begi.) } \\
\text { Irregular } \\
\text { (from past few } \\
\text { yrs) }\end{array}$ & $\begin{array}{c}8(23.52 \%) \\
18(52.94 \%) \\
8(23.52 \%)\end{array}$ & $\begin{array}{l}42(63.64 \%) \\
14(21.22 \%) \\
10(15.16 \%)\end{array}$ & 14.4 & 0.0007 \\
\hline 3 & $\begin{array}{l}\text { Length of } \\
\text { cycle }\end{array}$ & $\begin{array}{c}3 \text { days } \\
3 \text { - } 5 \text { days } \\
>1 \text { week }\end{array}$ & $\begin{array}{c}15(44.11 \%) \\
8(23.52 \%) \\
10(29.41 \%)\end{array}$ & $\begin{array}{l}14(21.2 \%) \\
13(19.7 \%) \\
39(59.1 \%)\end{array}$ & 8.3 & 0.01 \\
\hline 4 & $\begin{array}{l}\text { Type of } \\
\text { periods }\end{array}$ & $\begin{array}{c}\text { Heavy } \\
\text { Very heavy } \\
\text { Light } \\
\text { Very light }\end{array}$ & $\begin{array}{c}13(38.2 \%) \\
07(20.58 \%) \\
11(32.35 \%) \\
03(8.82 \%)\end{array}$ & $\begin{array}{c}14(21.22 \%) \\
5(7.58 \%) \\
20(3.3 \%) \\
37(56.07 \%)\end{array}$ & 8.31 & 0.03 \\
\hline 5 & $\begin{array}{c}\text { Abdominal } \\
\text { pain during } \\
\text { periods }\end{array}$ & $\begin{array}{c}\text { Yes } \\
\text { No } \\
\text { Sometimes }\end{array}$ & $\begin{array}{c}16(47.0 \%) \\
6(17.64 \%) \\
12(35.29 \%)\end{array}$ & $\begin{array}{c}47(71.22 \%) \\
2(3.04 \%) \\
17(25.76 \%)\end{array}$ & 7.20 & 0.02 \\
\hline 6 & $\begin{array}{l}\text { When does } \\
\text { the pain } \\
\text { start, if } \\
\text { observed? }\end{array}$ & $\begin{array}{c}\text { By onset } \\
\text { By end } \\
\text { In between } \\
\text { All the time } \\
\text { Only at beginning } \\
\text { or end }\end{array}$ & $\begin{array}{c}6(17.64 \%) \\
7(20.58 \%) \\
2(5.88 \%) \\
11(32.35 \%) \\
8(23.52 \%)\end{array}$ & $\begin{array}{c}3(4.55 \%) \\
6(9.1 \%) \\
11(16.67 \%) \\
34(51.52 \%) \\
12(18.2 \%)\end{array}$ & 10.7 & 0.02 \\
\hline 7 & $\begin{array}{l}\text { Does it } \\
\text { radiate to } \\
\text { posterior } \\
\text { part of } \\
\text { limbs? }\end{array}$ & $\begin{array}{c}\text { Yes } \\
\text { No } \\
\text { Maybe }\end{array}$ & $\begin{array}{c}19(55.89 \%) \\
4(11.77 \%) \\
11(32.36 \%)\end{array}$ & $\begin{array}{c}14(21.22 \%) \\
8(12.13 \%) \\
14(21.22 \%)\end{array}$ & 12.9 & 0.001 \\
\hline 8 & $\begin{array}{c}\text { Do u need } \\
\text { any } \\
\text { painkillers? }\end{array}$ & $\begin{array}{c}\text { Yes } \\
\text { No } \\
\text { Sometimes }\end{array}$ & $\begin{array}{c}15(44.11 \%) \\
6(17.65 \%) \\
13(32.24 \%)\end{array}$ & $\begin{array}{l}25(37.88 \%) \\
03(12.13 \%) \\
38(57.58 \%)\end{array}$ & 6.14 & 0.04 \\
\hline 9 & $\begin{array}{l}\text { Does ever } \\
\text { period } \\
\text { occurs twice } \\
\text { a month? }\end{array}$ & $\begin{array}{c}\text { Yes } \\
\text { No } \\
\text { Initially } \\
\text { Since begin. }\end{array}$ & $\begin{array}{c}14(41.18 \%) \\
03(8.83 \%) \\
05(14.7 \%) \\
12(35.3 \%)\end{array}$ & $\begin{array}{l}10(15.16 \%) \\
14(21.22 \%) \\
10(15.16 \%) \\
32(48.49 \%)\end{array}$ & 9.24 & 0.02 \\
\hline 10 & $\begin{array}{l}\text { Presence of } \\
\text { Facial hair }\end{array}$ & $\begin{array}{l}\text { Yes } \\
\text { No }\end{array}$ & $\begin{array}{l}24(70.59 \%) \\
10(29.42 \%)\end{array}$ & $\begin{array}{l}31(46.97 \%) \\
35(53.04 \%)\end{array}$ & 5.05 & 0.02 \\
\hline 11 & $\begin{array}{l}\text { Presence of } \\
\text { Acne }\end{array}$ & $\begin{array}{c}\text { Yes } \\
\text { No } \\
\text { Sometimes }\end{array}$ & $\begin{array}{c}28(82.36 \%) \\
04(11.77 \%) \\
02(5.89 \%)\end{array}$ & $\begin{array}{c}39(59.1 \%) \\
19(28.79 \%) \\
08(12.13 \%)\end{array}$ & 5.51 & 0.06 \\
\hline 12 & $\begin{array}{c}\text { Presence of } \\
\text { Stretch } \\
\text { marks }\end{array}$ & $\begin{array}{c}\text { Yes } \\
\text { No } \\
\text { Maybe }\end{array}$ & $\begin{array}{c}12(35.3 \%) \\
15(44.12 \%) \\
07(20.59 \%)\end{array}$ & $\begin{array}{c}40(60.7 \%) \\
15(22.73 \%) \\
11(16.17 \%)\end{array}$ & 6.37 & 0.04 \\
\hline 13 & $\begin{array}{l}\text { Is Skin } \\
\text { darkening } \\
\text { around } \\
\text { neck? }\end{array}$ & $\begin{array}{l}\text { Yes } \\
\text { No }\end{array}$ & $\begin{array}{l}28(82.35 \%) \\
10(29.42 \%)\end{array}$ & $\begin{array}{l}59(89.4 \%) \\
07(10.7 \%)\end{array}$ & 4.35 & 0.03 \\
\hline 14 & $\begin{array}{l}\text { Any other } \\
\text { psycological } \\
\text { effected } \\
\text { during } \\
\text { periods. }\end{array}$ & $\begin{array}{l}\text { Depression } \\
\text { Mood swings }\end{array}$ & $\begin{array}{c}14(41.18 \%) \\
20(58.8 \%)\end{array}$ & $\begin{array}{l}47(71.22 \%) \\
19(28.79 \%)\end{array}$ & 8.50 & 0.003 \\
\hline & & & & & & \\
\hline
\end{tabular}

$55.89 \%$ in adolescents and $21.22 \%$ in reproductive age group population respondents mentioned that they had experienced pain radiating to the posterior part of lower limbs. $62.4 \%$ of the respondents felt that the confronted pain was severe and there was a need of taking painkiller. $44 \%$ respondents had been experiencing periods twice a month for couple of months.

$29.42 \%$ in adolescents and $53.04 \%$ in reproductive age group population respondents answered that they did not experience any increased or abnormal facial hair growth whilst $70.59 \%$ in adolescents and $46.97 \%$ in reproductive age 
group population of them experienced such a growth in facial hair.

$82.36 \%$ in adolescents and $59.1 \%$ in reproductive age group responded in affirmation about having history of acne. $35.3 \%$ in adolescents and $60.7 \%$ in reproductive age group respondents noticed stretch marks on their bodies, especially near the areas of neck or stomach. $82.35 \%$ adolescents and $89.4 \%$ in reproductive age group population responded by stating that they encountered skin darkening near their neck region.

Almost in all adolescents and reproductive age group faced depression and severe mood swings.

\section{DISCUSSION}

Along with increased workload and less hours of sleep, the human efficiency is reduced, and brain starts losing its attentiveness and sharpness. The situation is called the 'situational stress'. In the survey, $76.47 \%$ in adolescents and $7.58 \%$ in reproductive age group population of respondents showed the situational stress, which is a cause of concern. With inefficiency leaping and ability to complete targets on time diminishing, a person is bound to develop "anger issues". In the present survey too, $44.11 \%$ in adolescents and $72.73 \%$ in reproductive age group population of total respondents experienced the same phenomenon. As proved by various post research too, stress mainly triggers the HPA axis and thus causes an abnormal release of hormone LH, which triggers the problems like hyperandrogenism. When in an abnormal amount it causes anovulation as ovaries fail to produce matured ovum. Due to some underlying unknown factors, the ovaries may produce ovum, maybe after a long time of stoppage or maybe twice a month. Now, the periods which are occurring may be normal or maybe very light or very heavy.

As seen in Table 4, 52.94\% in adolescents and $21.22 \%$ in reproductive age group population of the respondents had stated for having an irregular cycle since menarche, $8.82 \%$ in adolescents and $56.07 \%$ in reproductive age group population had mentioned for having very light periods and $20.58 \%$ in adolescents and $7.58 \%$ in reproductive age group population had very heavy menses. $41.18 \%$ in adolescents and $15.16 \%$ in reproductive age group population even mentioned that they had periods twice a month.

As LH level is increased abnormally and also as one of its main features is to convert into oestrogen with insulin, which is now, not being fulfilled because of hyperandrogenism, body shows some symptoms such as facial hair (or hirsutism), acne, stretch marks, skin darkening (acanthosis nigricans, mostly near armpits or neck).

In our survey, $70.59 \%$ in adolescents and $46.97 \%$ in reproductive age group population respondents responded 'Yes' facial hair, $82.36 \%$ in adolescents and $59.1 \%$ in reproductive age group population had stated that had acne. $35.3 \%$ in adolescents and $60.7 \%$ in reproductive age group population respondents by stating that they had developed stretch marks and $82.35 \%$ in adolescents and $89.4 \%$ in reproductive age group population confirmed, that they experienced abnormal skin darkening.

Normally during situation of panic or stress, the brain stimulates adrenal glands to release hormone cortisol, which regulates the body fluids, BP and blood sugar levels. An increased cortisol secretion level increases the blood glucose level. In prolonged stress, the normal amount of insulin is released, which falls short to cope up with the increased blood glucose. Thus, patients of PCOS often complain of diabetes mellites type 2 .

During our survey, it was found that many females were unable to figure out the reasons for developing various symptoms that were occurring to them and the remedial action for the same. Through the survey, a brief introduction on PCOS was given which made the doubts in the mind of certain respondents clear.

The limitation of the study was that the sample size was restricted to a small number mainly due to restrictions prevailing in Covid pandemic period. The study could have been made on large scale in the normal circumstances to bring in sharper results.

On analysing data received from our respondents, it can be stated that along with all the other factors, stress is a major (or catalytic) factor for causing PCOS and that PCOS can be treated very effectively without use of medicines by simply prescribing amendments or changes in person's lifestyle. a daily routine of yoga, meditation/exercise etc. Effects of various exercises can be described on regulating the effect of PCOS as under -

Yoga or Meditation - May calm stressed mind

Exercise - May reduce weight

Regulating diet - Will prevent the person from having more of fats, guiding towards more natural foods, having all the items of more nutritional value.

\section{CONCLUSIONS}

Aetiology of PCOS is yet to be completely understood Modifications in lifestyles / dietary habits could control and improve the situation. Healthy lifestyle certainly helps in the treatment but is not a complete cure for PCOS.

Data sharing statement provided by the authors is available with the full text of this article at jemds.com.

Financial or other competing interests: None.

Disclosure forms provided by the authors are available with the full text of this article at jemds.com.

\section{REFERENCES}

[1] Rao M, Shane BK, LeMieux LJ, et al. Cross-sectional study on the knowledge and prevalence of PCOS at a multiethnic university, Progress in Preventive Medicine: 2020;5(2):e0028.

[2] Nivetha M, Suganya SG. Survey of poly cystic ovarian disease (pcod) among the girl students of Bishop Heber College, Tiruchirapalli, Tamil Nadu, India. Journal of Nursing and Health Science 2016;05(4):44-52.

[3] Stein IF, Leventhal MN. Amenorrhoea associated with biral polycystic ovaries. American Journal of Obstetrics and Gynaecology 1935;29:181.

[4] March WA, Moore VM, Wilson KJ, et al. The prevalence of polycystic ovary syndrome in a community sample 
assessed under contrasting diagnostic criteria. Hum Reprod 2010;25(2):544-51.

[5] Yildiz BO, Bozdag G, Yapici Z, et al. Prevalence, phenotype and cardiometabolic risk of polycystic ovary syndrome under different diagnostic criteria. Hum Reprod 2012;27(10):3067-73.

[6] Tomlinson J, Letherby G, Pinkney J, et al. Raising awareness of Polycystic ovarian syndrome. Nurs Stand 2013;27(40):35-9.

[7] Williams T, Mortada R, Porter S. Diagnosis and treatment of polycystic ovary syndrome. American Family Physician 2016;94(2):106-13.

[8] Teede HJ, Misso ML, Deeks AA, et al. Assessment and management of poly cystic ovary syndrome: summary of an evidence-based guideline. Med J Aust 2011;195(6):S65-112.

[9] Diamanti-Kandarakis E, Dunaif A. Insulin resistance and the polycystic ovary syndrome revisited: an update on mechanisms and implications. Endocr Rev 2012;33(6):981-1030.

[10] Trivax B, Azziz R. Diagnosis of polycystic ovary syndrome. Clin Obstet Gynecol 2007;50(1):168-77.

[11] Legro RS, Kunselman AR, Dodson WC, et al. Prevalence and predictors of risk for type 2 diabetes mellitus and impaired glucose tolerance in polycystic ovary syndrome: A prospective, controlled study in 254 affected women. J Clin Endocrinol Metab 1999;84(1):165-9.

[12] Escobar-Morreale HF, Botella-Carretero JI, AlvarezBlasco F, et al. The polycystic ovary syndrome associated with morbid obesity may resolve after weight loss induced by bariatric surgery. J Clin Endocrinol Metab 2005;90:6364-9.

[13] Apridonidze T, Essah PA, Iuorno MJ, et al. Prevalence and characteristics of the metabolic syndrome in women with polycystic ovary syndrome. J Clin Endocrinol Metab 2005;90(4):1929-35.

[14] Palomba S, de Wilde MA, Falbo A, et al. Pregnancy complications in women with polycystic ovary syndrome. Hum Reprod Update 2015;21(5):575-92.

[15] Zangeneh ZF, Naghizadeh MM, Masoumi M. Polycystic ovary syndrome and circulating inflammatory markers. Int J Reprod Biomed 2017;15(6):375-82.

[16] Teede H, Deeks A, Moran L. Polycystic ovary syndrome: a complex condition with psychological, reproductive and metabolic manifestations that impacts on health across the lifespan. BMC Med 2010;8:41.

[17] Janssen OE, Hahn S, Tan S, et al. Mood and sexual function in polycystic ovary syndrome. Semin Reprod Med 2008;26(1):45-52.

[18] Glintborg D, Andersen M. Medical treatment and comorbidity in polycystic ovary syndrome: an updated review. Current Opinion in Endocrine and Metabolic Research 2020;12:33-40.

[19] Moran LJ, March WA, Whitrow MJ, et al. Sleep disturbances in a community-based sample of women with polycystic ovary syndrome. Hum Reprod 2015;30(2):466-472.

[20] Ehrmann DA. Metabolic dysfunction in PCOS: relationship to obstructive sleep apnea. Steroids 2012;77 (4):290-94.
[21] Legro RS, Arslanian SA, Ehrmann DA, et al. Diagnosis and treatment of polycystic ovary syndrome: an endocrine society clinical practice guideline. J Clin Endocrinol Metab 2013;98(12):4565-92.

[22] Carmina E, Oberfield SE, Lobo RA. The diagnosis of polycystic ovary syndrome in adolescents. Am J Obstet Gynecol 2010;203(3):201.e1-5.

[23] Dumesic DA, Lobo RA. Cancer risk and PCOS. Steroids 2013;78(8):782-5.

[24] Patel S. Polycystic ovary syndrome (PCOS), an inflammatory, systemic, lifestyle endocrinopathy. J Steroid Biochem Mol Biol 2018;182:27-36.

[25] Melo AS, Ferriani RA, Navarro PA. Treatment of infertility in women with polycystic ovary syndrome: approach to clinical practice. Clinics (Sao Paulo) 2015;70(11):765-9.

[26] Franks S, Gharani M, Waterworth D, et al. The genetic basis of polycystic ovary syndrome. Hum Reprod 1997;12(12):2641-8.

[27] Player MS, King DE, Mainous AG, et al. Psychosocial factors and progression from prehypertension to hypertension or coronary heart disease. Ann Fam Med 2007;5(5):403-11.

[28] Street ME, Cirillo F, Catellani C, et al. Current treatment for Polycystic Ovary Syndrome: focus on adolescence. Minerva Pediatr 2020;72(4):288-311.

[29] Teede H, Deeks A, Moran L. Polycystic ovary syndrome: a complex condition with psychological, reproductive and metabolic manifestations that impacts on health across the lifespan. BMC Med 2010;8:41.

[30] Harrison CL, Lombard CB, Moran LJ, et al. Exercise therapy in polycystic ovary syndrome: a systematic review. Hum Reprod Update 2011;17(2):171-83.

[31] Farshchi H, Rane A, Love A, et al. Diet and nutrition in polycystic ovary syndrome (PCOS): pointers for nutritional management. J Obstet Gynaecol 2007;27(8):762-73.

[32] Sam S, Ehrmann DA. Metformin therapy for the reproductive and metabolic consequences of polycystic ovary syndrome. Diabetologia 2017;60(9):1656-61.

[33] Naderpoor N, Shorakae S, de Courten B, et al. Metformin and lifestyle modification in polycystic ovary syndrome: systematic review and meta-analysis. Hum Reprod Update 2015;21(5):560-74.

[34] Doom JR, Gunnar MR. Stress physiology and developmental psychopathology: past, present and future. Dev Psychopathol 2013;25(4 Pt 2):1359-73.

[35] Rosenfield RL, Ehrmann DA. The pathogenesis of polycystic ovary syndrome (PCOS): the hypothesis of PCOS as functional ovarian hyperandrogenism revisited. Endocr Rev 2016;37(5):467-520.

[36] Karrer-Voegeli S, Rey F, Reymond MJ, et al. Androgen dependence of hirsutism, acne and alopecia in women: retrospective analysis of 228 patients investigated for hyperandrogenism. Medicine (Baltimore) 2009;88(1):3245.

[37] Tirabassi G, Boscaro M, Arnaldi G. Harmful effects of functional hypercortisolism: a working hypothesis. Endocrine 2014;46(3):370-86. 